\title{
Keragaman Morfologi Ikan Nyalian (Rasbora Lateristriata, Bleeker) Pada Habitat Yang Berbeda
}

\author{
Sang Ayu Made Putri Suryani, I Made Kawan, I Wayan Arya \\ \{suryanip@rocketmail.com\} \\ Universitas Warmadewa, Bali, Indonesia
}

\begin{abstract}
Abstrak. Rasbora lateristriata has a declining population structure, especially in the upstream Sungi river. This is largely attributed to changes in environmental factors, such as the quality of the river water. The decline is also caused by the presence of fish varieties that interbreed with the natives, threatening their existence. In general, the varieties with morphological diversity have a better chance of adapting to environmental changes. The purpose of this study is to determine how the decline in Rasbora lateristriata fish can be prevented. The samples were taken at the upstream, branch, center, and downstream using purposive sampling, while data were analyzed by ANOVA using SPSS version 20. There were no significant differences in the colors of Rasbora lateristriata obtained in the upstream, midstream, branch, and downstream. The average resulting color was greyish black. Cluster Character SL, TL, and weight indicate that Rasbora lateristriata fits into three main clusters. The fist cluster is a grouping of upstream and downstream. The second one is the first cluster grouping with branches. The Cluster III is a grouping of Cluster II with the middle. The rich colors and morphometric of lateristriata Rasbora fish in the river are affected by water quality, including $\mathrm{DO}, \mathrm{pH}$, and temperature.
\end{abstract}

Keyword: Rasbora lateristriata, morphological diversity, water quality

\section{Pendahuluan}

Genus Rasbora tergolong kelas Cyprinidae memiliki 87 species yang terdistribusi meliputi wilayah Asia dan sebagian kecil Afrika. ${ }^{[1]}$ Menurut data fishbase, terdapat 90 spesies ikan Rasbora yang tersebar di seluruh dunia dimana 54 spesies terdistribusi di wilayah Indonesia dan 3 spesies adalah spesies endemik Indonesia. ${ }^{[2]}$ Dari data tersebut diketahui jumlah spesies ikan Rasbora di Indonesia berkisar antara 48\%-62\% dari total jumlah spesies yang ada di dunia. Rasbora adalah ikan air tawar yang mudah ditemukan pada sungai, danau, kolam, parit dan rawa-rawa yang kandungan oksigennya tinggi dan sungai yang arusnya tidak kuat. ${ }^{[3]}$ Beberapa penelitian menduga bahwa Rasbora baliensis dari Bali mirip dengan Rasbora lateristriata yang berasal dari bagian timur Pulau Jawa karena sangat sulit dibedakan secara morfologi. Rasbora laterisiata atau sering disebut Wader Pari merupakan salah satu ikan konsumsi yang berada di aliran sungai Yeh Sungi dan menjadi salah satu sumber biodiversitas bagi sumberdaya ikan di daerah tersebut. ${ }^{[4,5]}$ Ikan tersebut memiliki sebaran yang cukup luas dan merupakan ikan asli pada perairan tawar seperti sungai. Ukuran tubuhnya relatif kecil dan umumnya hidup di bagian 
pinggir sungai yang arusnya tidak deras dan bersifat Ominivora. ${ }^{[6]}$ Secara ekologis, Wader Pari atau di daerah Bali disebut Nyalian merupakan komponen penyusun keanekaragaman hayati di sungai dan sebagai pengisi relung bagi pemakan plankton dan pemanfaatan ikan nyalian oleh masyarakat setempat dilakukan melalui kegiatan penangkapan dengan jala lebar, pancing, dan bubu. Ikan wader merupakan salah satu ikan konsumsi sehingga dapat menjadi sumber pemenuhan protein bagi masyarakat. Upaya pengelolaan perikanan perlu dilakukan agar sumberdaya ikan khususnya wader dapat dimanfaatkan secara lestari dan berkelanjutan.

Identifikasi Ikan wader pari (Rasbora lateristiata) seperti gambar 2.1 ${ }^{[7,8]}$. Wader pari dapat dikenal melalui garis belang berwarna hitam memanjang mulai dari operculum hinggap pangkal sirip ekor. Memiliki gurat sisi yang lengkap dengan 29-33 sisik berpori hingga mencapai ekor dengan 7 baris sisik antara gurat sisi dengan pertengahan batang (caudal peduncle). Tepi sirip ekor berwarna kecoklatan. ${ }^{[7]}$ Posisi mulut ikan wader berada diujung dengan ukuran agak kecil terdapat bonggol atau sambungan tulang penyusun tulang rahang bawah dan tidak bersungut. Mulut ikan wader berbentuk miring dengan ujung depan setinggi mata dan rahang atas meluas dibawah batas mata. ${ }^{[5]}$

Sungai Sungi merupakan salah satu sungai dari sepuluh sungai yang mengalami penurunan kualitas yang disebabkan karena terkontaminasi oleh limbah. ${ }^{[9]}$ Parameter pencemar sungai telah melampaui baku mutu yaitu BOD, COD, Total Fosfat, Total Coliform dan Faecal coliform dimana kondisi ini penting untuk diperhatikan karena muara Sungai Sungi merupakan titik pengambilan air baku air minum PDAM Kabupaten Tabanan. ${ }^{[9]}$ Aktivitas pada Sungai Sungi didominasi oleh kegiatan pertanian, pemukiman, peternakan dalam skala rumah tangga dan industri yang terdapat di daerah hilir. Limbah dari aktivitas tersebut menyebabkan penurunan kualitas air yang dapat ditunjukkan karena terjadinya peningkatan kandungan BOD, COD, Total Fosfat dan bakteri Faecal Coliform. Peningkatan terjadi pada sungai bagian tengah dan menurun pada daerah hilir. Status mutu Sungai Sungi pada bagian hulu masih memenuhi kualitas air kelas 1 sedangkan bagian tengah dan hilir tergolong tercemar ringan dimana parameter kualitas air yang melampaui baku mutu air sungai adalah Total Fosfat $0,44 \mathrm{mg} / 1$ untuk bagian tengah, 0,40 $\mathrm{mg} / \mathrm{l}$ bagian hilir dan Faecal coliform dengan nilai rata-rata $166 / 100 \mathrm{ml}$ pada bagian tengah dan $152 / 100 \mathrm{ml}$ pada bagian hilir. ${ }^{[10]}$

\section{Metoda Penelitian}

Wilayah sungai Sungi akan dibagi menjadi 4 yaitu hulu, tengah, cabang dan hilir. Pada hulu titik $\left(8^{\circ} 21,45^{\prime} \mathrm{S}-115^{\circ} 10,49^{\prime} \mathrm{E}\right)$, tengah pada titik $\left(8^{\circ} 33,695^{\prime} \mathrm{S}-115^{\circ} 09,538^{\prime} \mathrm{E}\right)$, cabang pada titik cabang ( $8^{\circ} 22^{\prime} 25^{\prime}$ 'S-115'11'5'E) dan hilir pada titik ( $8^{\circ} 38,053$ 'S-115'06,068'E). Pengambilan sampel air dilakukan pada masing-masing habitat sebanyak 3 kali secara komposit. Sampel ikan dikumpulkan dari hasil penangkapan ikan Rasbora lateristriata pada bagian hulu, tengah, dan hilir Sungai Sungi.

Variabel yang diamati adalah: Kualitas air Sungai Sungi pada daerah hulu, tengah dan hilir seperti: suhu, DO dan $\mathrm{pH}$ dan Karakter morfologi populasi ikan Rasbora lateristriata pada sungai Sungi yaitu warna, panjang standar, panjang total dan berat

Materi koleksi sampel

1. Pengambilan sampel air. Botol sampel digunakan untuk mengambil sampel air yang akan dianalisis di lapangan seperti suhu, DO dan $\mathrm{pH}$ di analisis langsung pada lokasi penelitian yaitu pada bagian hulu, tengah dan hilir. Pengambilan sampel air dengan menggunakan metode sampel gabungan (composite sample) 
2. Koleksi Sampel ikan Sampel ikan dikoleksi pada bagian hulu, tengah dan hilir sungai sungi dengan menggunakan jala tebar sebanyak 3 buah dengan mata jala masing-masing $1,25 \mathrm{x}$ $1,25 \mathrm{~cm} ; 1 \times 1 \mathrm{~cm}$; dan $0,5 \times 0,5 \mathrm{~cm}$. sebanyak 10 ekor untuk masing-masing lokasi

Analisis Data

Analisis morfologi dan sebaran karakter morfometrik intra dan interpopulasi dilakukan dengan ANOVA menggunakan SPSS versi 20 dan disajikan dalam dendogr

\section{Hasil Dan Pembahasan}

\subsection{Warna}

Variasi warna yang didapat pada sungai Sungi tidak terdapat perbedaan yang signifikan yaitu pada hulu, tengah, cabang dan hilir. Warna yang diperoleh dari nilai Munsell Colour Analyser adalah berkisar antara 44,37 sampai 60.87 untuk nilai R, antara 37,54 sampai 50,95 untuk nilai $G$ dan nilai B antara 28,33 sampai 43.95. Perbedaan warna ikan Rasbora lateristriata pada hulu, Cabang, Tengah dan hilir tidak signifikan pada keenam titik sampelnya (tabel 1) tetapi terdapat perbedaan pada ulangan Tabel

Tabel 1. Nilai Rata-Rata Analisis Variasi Warna Pada Sungai Sungi

\begin{tabular}{lrrrc}
\hline Factor & N & Mean & StDev & $95 \%$ CI \\
\hline Hulu_R & 24 & 49.42 & 16.78 & $(43.66,55.17)$ \\
Hulu_G & 24 & 39.33 & 16.74 & $(33.58,45.09)$ \\
Hulu_B & 24 & 30.29 & 13.80 & $(24.54,36.05)$ \\
Cabang_R & 24 & 60.88 & 16.52 & $(55.12,66.63)$ \\
Cabang_G & 24 & 50.96 & 14.03 & $(45.20,56.71)$ \\
Cabang_B & 24 & 43.96 & 12.11 & $(38.20,49.71)$ \\
Tengah_R & 24 & 44.38 & 14.02 & $(38.62,50.13)$ \\
Tengah_G & 24 & 37.54 & 13.32 & $(31.79,43.30)$ \\
Tengah_B & 24 & 28.33 & 11.08 & $(22.58,34.09)$ \\
Hilir_R & 24 & 47.04 & 16.40 & $(41.29,52.80)$ \\
Hilir_G & 24 & 38.58 & 14.48 & $(32.83,44.34)$ \\
Hilir_B & 24 & 28.13 & 10.88 & $(22.37,33.88)$ \\
\hline \multicolumn{4}{c}{ Pooled StDev 14.3258}
\end{tabular}

Perbedaan warna pada hulu, tengah, cabang dan hilir tidak berbeda signifikan karena kemampuan adaptasi spesies ikan Rasbora lateristriata pada masing masing habitat terhadap paparan kualitas air adalah sama

Tabel 2 Hubungan Variasi Warna Antar Grup Lokasi

\begin{tabular}{lrrcrr}
\hline Difference of Levels & $\begin{array}{r}\text { Difference } \\
\text { of Means }\end{array}$ & $\begin{array}{r}\text { SE of } \\
\text { Difference }\end{array}$ & 95\% CI & T-Value & $\begin{array}{r}\text { Adjusted } \\
\text { P-Value }\end{array}$ \\
\hline Hulu_R - Cabang_R & -11.46 & 4.14 & $(-21.70,0.00)$ & -2.77 & 0.023 \\
Hulu_G - Cabang_R & -21.54 & 4.14 & $(-31.78,0.00)$ & -5.21 & 0.000 \\
Hulu_B - Cabang_R & -30.58 & 4.14 & $(-40.82,0.00)$ & -7.40 & 0.000 \\
Cabang_R - Cabang_G & 9.92 & 4.14 & $(-0.32,20.16)$ & 2.40 & 0.060 \\
Cabang_G - Cabang_R & -9.92 & 4.14 & $(-20.16,0.32)$ & -2.40 & 0.060
\end{tabular}




\begin{tabular}{llllll} 
Cabang_B - Cabang_R & -16.92 & 4.14 & $(-27.16,0.00)$ & -4.09 & 0.000 \\
Tengah_R - Cabang_R & -16.50 & 4.14 & $(-26.74,0.00)$ & -3.99 & 0.000 \\
Tengah_G - Cabang_R & -23.33 & 4.14 & $(-33.57,0.00)$ & -5.64 & 0.000 \\
Tengah_B - Cabang_R & -32.54 & 4.14 & $(-42.78,0.00)$ & -7.87 & 0.000 \\
Hilir_R - Cabang_R & -13.83 & 4.14 & $(-24.07,0.00)$ & -3.35 & 0.004 \\
Hilir_G - Cabang_R & -22.29 & 4.14 & $(-32.53,0.00)$ & -5.39 & 0.000 \\
Hilir_B - Cabang_R & -32.75 & 4.14 & $(-42.99,0.00)$ & -7.92 & 0.000 \\
\hline
\end{tabular}

Individual confidence level $=98.61 \%$

\subsection{Karakter Panjang total (TL), panjang standar (SL) dan Berat}

Analisis pengelompokan dengan amalgam step yaitu data rataan panjang standar, panjang total dan berat diperoleh seperti tabel 3

Tabel 3. Pengelompokan Variable Berat, Panjang Standard(SL) dan Panjang Total (TL)

\begin{tabular}{lllll}
\hline Variable & Cluster1 & Cluster2 & Cluster3 & $\begin{array}{l}\text { Grand } \\
\text { centroid }\end{array}$ \\
\hline Berat_gr & 3.0417 & 2.6995 & 4.6545 & 3.3594 \\
SL_mm & 53.3002 & 48.6525 & 62.5130 & 54.4415 \\
TL_mm & 66.3663 & 60.3290 & 78.0085 & 67.7675 \\
\hline
\end{tabular}

Tabel 4. Jarak antar kelompok lokasi

\begin{tabular}{llll}
\hline & Cluster1 & Cluster2 & Cluster3 \\
\hline Cluster1 & 0.0000 & 7.6267 & 14.9338 \\
Cluster2 & 7.6267 & 0.0000 & 22.5499 \\
Cluster3 & 14.9338 & 22.5499 & 0.0000 \\
\hline
\end{tabular}

Dari jarak antar kluster diperoleh jarak terdekat adalah antara kelompok 2 dan kelompok 1 sedangkan jarak terjauh adalah pada kelompok 2 dan kelompok 3.

\subsection{Analisis Kualitas Air}

Hasil pengukuran kualitas air Sungai Sungi sepert tertera pada Tabel 5 Parameter fisik yaitu suhu air berkisar $23-28{ }^{\circ} \mathrm{C}$. Parameter kimiawi dimana DO berkisar 5.86-6.16 ppm, pH perairan berkisar 6.50- 7.55. Dilihat dari beberapa parameter, kualitas air memiliki perubahan dari hulu sampai hilir. Kondisi ini di sebabkan karena disepanjang aliran sungai Sungi sudah menerima berbagai macam masukkan bahan organik seperti ditunjukkan nilai $\mathrm{pH}$ yang bervariasi dan cendrung asam pada hulu dan basa pada hilir. Tetapi nilai $\mathrm{pH}$ ini masih bisa ditoleransi oleh kehidupan ikan yaitu 4-11.R lateristriata banyak ditemukan pada tengah yang kandungan oksigen nya berkisar 6.10- 7.08 ppm

Tabel 5 Hasil Pengukuran sifat fisik - kimiawi Perairan Sungai Sungi kisaran parameter fisik kimiawi stasiun penelitian

\begin{tabular}{ccll}
\hline Stasiun & DO $(\mathrm{Ppm})$ & $\mathrm{pH}$ & Suhu $\left({ }^{\circ} \mathrm{C}\right)$ \\
\hline 1 & 6.40 & 6.50 & 24 \\
2 & 6.10 & 7.32 & 27 \\
3 & 5.86 & 7.55 & 28 \\
4 & 6.16 & 7,32 & 23 \\
\hline Kisaran & $5.86-6.16$ & $6.50-7.55$ & $23-28$ \\
\hline
\end{tabular}




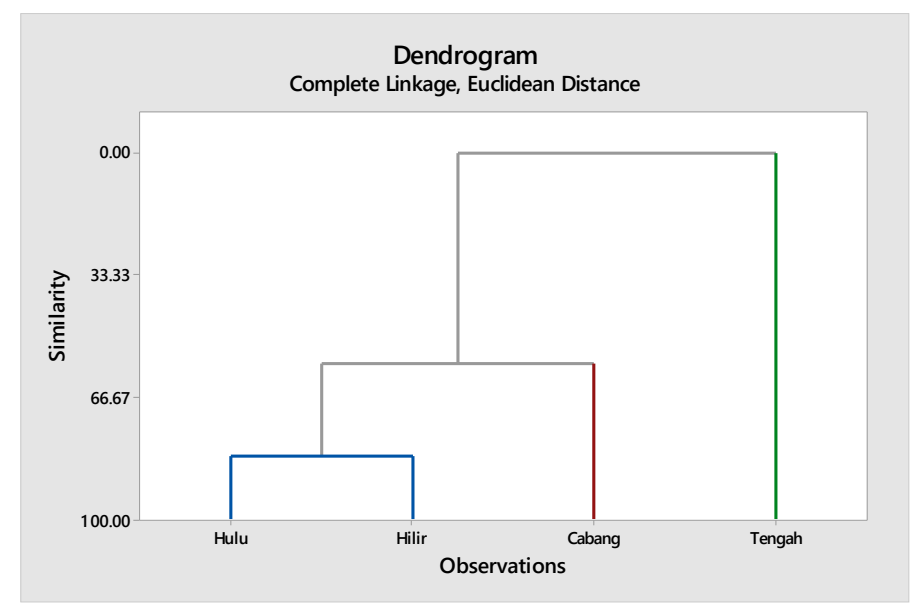

Gambar 1 Dendogram berdasarkan SL,TL dan berat

Hasil analisis kluster menggunakan jarak Euclidean menunjukkan bahwa Rasbora lateeristriata dari empat populasi yaitu hulu, cabang, tengah dan hilir mengelompok ke dalam 3 kluster utama. Klaster satu pengelompokan antara hulu dan hilir, klaster kedua adalah grup cabang dan claster ketiga adalah grup tengah. (Gambar 1)

\section{Kesimpulan}

Berdasarkan hasil penelitian serta pembahasan maka dapat ditarik simpulan sebagai berikut

1. Karakter morfologi berdasarkan warna menunjukkan bahwa pada daerah hulu, tengah, cabang dan hilir warna Rasbora lateristriata memiliki warna keabu-abuan sampai hitam

2. Karakter morfologi berdasarkan panjang total, panjang standard dan berat membentuk kelompok yang membaur menjadi 3 kluster. Kluster I adalah hulu dan hilir yang memiliki similaritas tertinggi.Kluster II dimana kelompok I membentuk kluster dengan cabang dan Kluster III dengan Tengah yang memiliki similaritas terjauh

\section{Ucapan Terimakasih}

Terima kasih kami ucapkan kepada

1. Lembaga Penelitian Universitas Warmadewa yang telah mensubsidi dana penelitian sehingga penelitian ini dapat kami selesaikan tepat waktu

2. Kelompok Mina Ayu Kecamatan Marga Tabanan yang telah membentu kami dalam pengambilan sampel ikan dan air

\section{References}

[1] Eschemeyer, M. R. 1998. Catalog of fishes: genera, species, references http://researcharchieve.calacademy.org/research/ichtyologi/catalog/fishcatmain.asp.

[2] Fishbase. 2016. Rasbora lateristriata (Bleeker, 1854). Tersedia di: http://www.fishbase.org/summary/5167. 
[3] Brittan.M.R. 1998. Rasbora: keeping and breeding them in captivity. T.F.H Publications, Neptune City, New Jersey

[4] Schuster, W.H. and R. Djajadiredja, 1952. Local common names of Indonesian fishes. W.V. Hoeve, Bandung, Indonesia. 276p.

[5] Saanin, H. 1984. Taksonomi dan Kunci Identifikasi Ikan I. Penerbit Binacipta.

[6] Sjafei, D.S., Wirjoatmodjo, S., Rahardjo, M. F., dan Susilo, B. S. 2001. Fauna Ikan di Sungai Cimanuk Jawa Barat. Jurnal Iktiologi Indonesia Vol. 1 No. 1: 1-6.

[7] Kottelat, M., Tan, H. H. 1993. Boraras micros, a new genus and species of minute freshwater fish from Thailand (Teleostei: Cyprinidae) Ichtyol. Explor. Freshwater

[8] Sterba, G. 1989. Freshwater Fishes of the World. Volume 1. Falcon Books: New Delhi.

[9] BLH Prov. Bali. 2009. Status Lingkungan Hidup Daerah Provinsi Bali. Denpasar.

[10] Setiari, N. M., Mahendra, Sudiana, M. \& Suyasa, I.W.Y. 2012. Identifikasi Sumber Pencemar dan Analisis Kualitas Air Tukad Yeh Sungi Di Kabupaten Tabanan Dengan Metode Indeks Pencemaran. Ecotrophic. Vol 7 (1). p. 40-46. 